TECHNICAL TRANSACTIONS 12/2019

MECHANICS

DOI: $10.4467 / 2353737$ XCT.19.130.11455 SUBMISSION OF THE FINAL VERSION: 11/12/2019

\author{
Małgorzata Kuźnar (D) orcid.org/0000-0002-2876-4964 \\ malgorzata.kuznar@mech.pk.edu.pl \\ Cracow University of Technology, Reliability and Technical Exploitation Division, \\ Cracow, Poland
}

\title{
PREDICTION OF THICKNESS OF PANTOGRAPH CONTACT STRIPS USING Artificial Neural Networks
}

\author{
PREDYKCJA GRUBoŚCI NAKŁADKI ŚLIZGOWEJ ODBIERAKA PRĄDU \\ PRZY UŻYCIU SZTUCZNYCH SIECI NEURONOWYCH
}

\begin{abstract}
The sliding strip of the current collector (pantograph) of a rail vehicle is an element directly cooperating with the catenary and is exposed to abrasion, electric discharge and various types of damage. It is therefore the most frequently replaced element. However, often sliding strips are exchanged before exceeding the limit thickness value, which increases the costs related to technical maintenance. Because the wear process is dependent on many factors, heuristic methods are necessary to predict the thickness of the sliding strip. Knowing the predicted thickness value, it will be possible to adapt the maintenance cycle. In the article, the results of simulations carried out based on the developed structure of the artificial neural network are also presented.
\end{abstract}

Keywords: rail vehicles, pantograph, current collector, thickness prediction, sliding cover, artificial neural networks, ANN

\section{Streszczenie}

Nakładka ślizgowa odbieraka prądu pojazdu szynowego jest elementem bezpośrednio wspólpracującym z siecią trakcyjną w związku, z czym narażona jest na zużycie ścierne, elektroerozyjne oraz różnego rodzaju uszkodzenia. Jest, zatem elementem najczęściej wymienianym. Często jednak nakładki wymieniane są przed przekroczeniem granicznej wartości grubości, co zwiększa koszty związane z obsługą techniczną. Ponieważ proces zużycia jest zależny od wielu czynników, dlatego do predykcji grubości nakładki ślizgowej niezbędne jest zastosowanie metod heurystycznych. Znając prognozowaną wartość grubości, możliwe będzie odpowiednie dostosowanie cyklu utrzymania. W artykule przedstawiono wyniki symulacji przeprowadzonych na podstawie opracowanej struktury sztucznej sieci neuronowej.

Słowa kluczowe: pojazdy szynowe, pantograf, odbierak prądu, predykcja grubości, nakładka ślizgowa, sztuczne sieci neuronowe, SSN 


\section{Introduction}

The current collector, commonly called the pantograph (Fig. 1), is used to receive current from the overhead lines to feed a traction vehicle. Due to the fact that it is an element directly cooperating with the catenary, it is exposed to operational wear and various types of damage that may arise during usage.

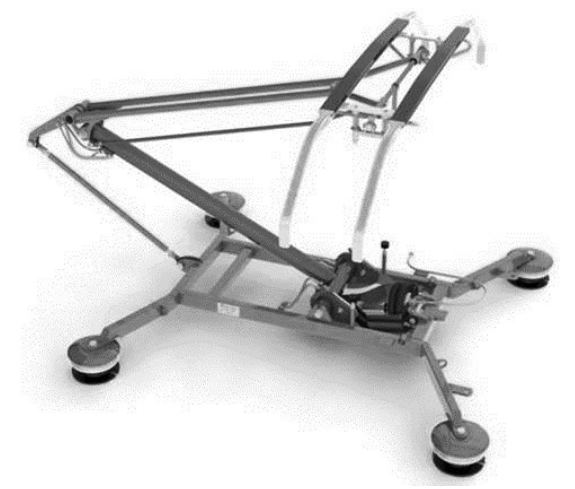

Fig. 1. Current collector (pantograph 160EC [1])

In railroads, it is a common problem to find out the cause of current collector damage. This is a significant problem because the Rail Infrastructure Manager is responsible for the condition of the overhead contact line, while the railway carrier is responsible for the condition of the current collector. In the event of a network failure due to poor technical condition of the current collector, the cost of repairs must be borne by the railway carrier. In the event of damage due to an incorrect condition of the overhead contact line, the costs lie with the infrastructure manager. Currently, in case of such events, a committee is called to determine the cause of damage of the current collector and the overhead contact line. In many cases, this is a subject of dispute due to the lack of methods allowing for a clear assessment of the cause of current collector damage.

The sliding strip, which is part of the direct co-operation of the pantograph with the overhead catenary wire, is exposed to the greatest operational wear. The reason for replacing the contact strips, beyond the mentioned wear, may be damage to the sliding strip surface. Having data on operating parameters such as level of carbon strip wear, vibrations of a current collector or the pantograph - catenary contact force, and information about the cause of replacement of the contact strips and the pantograph, it would be possible to deduce the cause of damage both the contact strips and the entire pantograph.

This article summarizes the most common causes of replacement of carbon strips of the current collector with possible causes of damage. The scale of the problem has been identified based on data from pantograph measurement notes. Over 1500 measurements of 62 locomotives of type EP09 and EU07 were analysed. Properly prepared and digitalized data from the measurement notes were used as input data to teach an artificial neural network that was designed to predict the degree of wear of carbon contact strips. 


\section{Causes of replacement and damage of contact strips}

Numerous scientific papers deal with the problem of interaction between catenary and current collector [2-11]. In order to keep the contact between the contact strip with the catenary, it is necessary to maintain the appropriate force on the current collector. In case of too much force, mechanical damage may occur to both the current collector and the overhead contact line, while in the case of too little an electric arc is produced which causes overburning and thus excessive wear of the carbon strips.

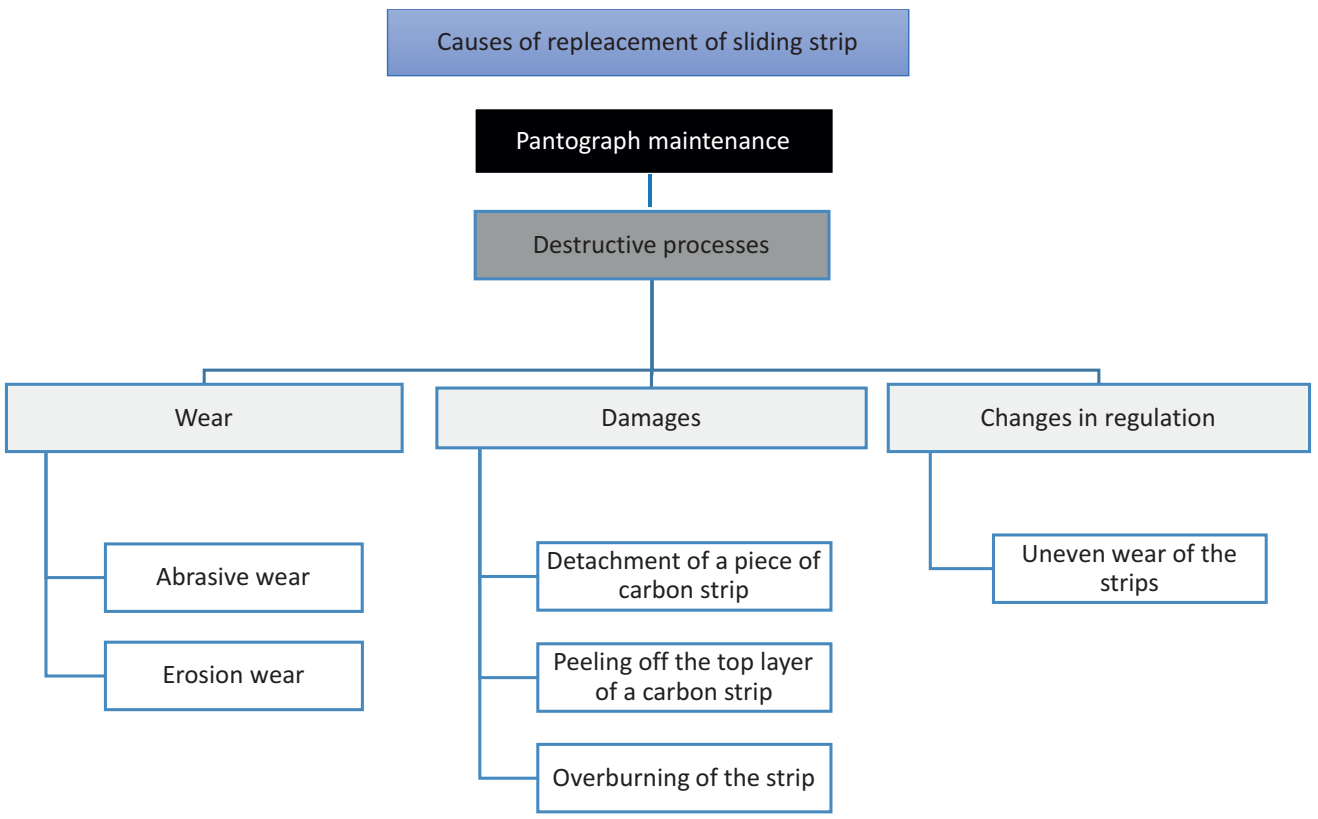

Fig. 2. Reasons for replacing the pantograph contact strips

When using the current collector, the carbon contact strips wears off. If the thickness of the strip is less than the recommended value in the measurement note, the contact strip should be replaced with a new one. In practice, the carbon strips are replaced a little earlier to eliminate over-wear of the strip, which could result in more expensive damage to the current collector and the overhead contact line. However, when the strip is replaced with no obvious signs of damage, we say that the contact strip is replaced because of operational wear. Otherwise, the causes of replacement are various types of damage. The most common damage to carbon strips can include cracks in the strip, detachment of a piece of carbon strip, peeling off the top layer of a carbon strip, uneven wear of the strips, or overburning of the strip. Figure 2 shows as an example the reasons for replacing current collector carbon strips.

Each of the reasons for replacement is caused by a different type of destructive process. During maintenance, the sliding strip wears out by an abrasive or erosion process. When the overlay thickness reaches the recommended minimum thickness, it is necessary to replace the overlay with a new one. The defects generated during the design and manufacturing the 
pantograph contact strips may be manifested during the use in the form of detachment of a bigger piece of carbon strip or detachment pf only the top layer of a carbon strip. Such cases are usually caused by a material defect. According to the literature $[12,13]$, carbon strip detachment may be also caused by excessive wear or hitting in the hinder on an overhead contact line (e.g. improperly mounted section isolator, hanger elements, ice or external elements like tree branches). Another type of contact strip damage is overburning, which can be caused by an electric arc that can be formed in bad weather conditions (rain, snow, overhead contact), and too little pressure between the pantograph and the overhead line [13]. The cause of uneven wear of slides may be incorrect fitting of the carbon strips in the slide plate or incorrect maintenance of the technical condition of the mechanism, which pushes a contact shoe up against the overhead contact wire.

At present, the pantograph measurement note does not include information such as reason of replacing the contact strip and replacing the entire current collector, which is a problem when concluding the potential causes of damage. From the operational point of view, it is important to replace the contact strip before it causes more expensive damage. This may be done using a prediction method. The author decided to use an Artificial Neural Network to forecast a future value of contact strip thickness, because of their ability to map complex non-linear functions.

\section{Simulation of wear of carbon contact strips}

The methodology for empirical research involved several basic stages:

- collecting data from current collector measurements,

- data analysis and selection,

- developing learning data structures,

- development of artificial neural network architecture,

- testing of artificial neural networks,

- comparison of prediction results,

- selection of the neural network that gives the most accurate prediction of overlay thickness.

In order to predict the consumption of carbon contact strips, properly prepared data from the current collector measurement notes were used as input and output data to teach the artificial neural network.

The input structure of the artificial neural network was developed on the basis of data from the measuring notes of the current collectors as well as information about the replacement of sliding strips and the replacement of the current collector. Data from 62 different locomotives were analysed, which represented 1537 measurements. Measurements were made monthly, and concerned the locomotive number, the pantograph type, the thickness of the carbon contact strips, and the pantograph number.

In the next step, the structure of the Artificial Neural Network was established. In order to conduct the simulation, the ANN structure which gives the best results was chosen. The 
network structure was selected from among 20 other structures based on the smallest mean square error. Therefore, in this paper a Feed-Forward network with backward propagation is presented, containing 6 layers of 10 neurons in each layer, and one output layer comprising 8 neurons. The back error propagation algorithm requires the activation function to be continuous and differentiable, which is why a tangentoidal activation function was used. The Levenberg-Marqardt learning algorithm was also used due to the fact that it is currently one of the most commonly used algorithms for teaching one-way networks $[14,15]$. This is mainly due to its rapid convergence, not very great computational complexity, and simple implementation. The algorithm uses the solving of the non-linear problem of the least squares presented by Marquardt in work [16]. The structure of the artificial neural network developed within the frame of this work is presented in Figure 3 and in equation (1).

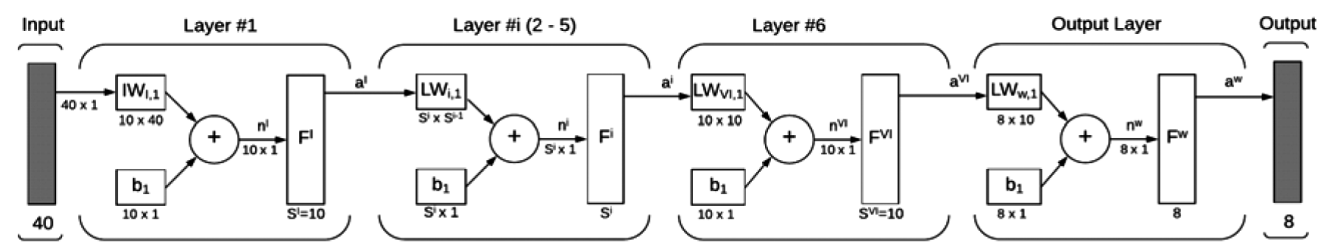

Fig. 3. Structure of Artificial Neural Network used to predict the thickness of carbon contact strip

$$
\begin{aligned}
& a^{w}=F^{w}\left(L W _ { ( W , \mathrm { VI } } F ^ { \mathrm { VI } } \left(L W _ { \mathrm { VI } , \mathrm { V } } F ^ { \mathrm { V } } \left(L W _ { \mathrm { V } , \mathrm { IV } } F ^ { \mathrm { IV } } \left(L W _ { \mathrm { IV } , \mathrm { III } } F ^ { \mathrm { III } } ( L W _ { \mathrm { III } , \mathrm { II } } ) F ^ { \mathrm { II } } \left(L W_{\mathrm{II}, \mathrm{I}} F^{\mathrm{I}}\left(I W_{\mathrm{I}, \mathrm{I}} p+b_{1}\right)\right.\right.\right.\right.\right. \\
& \left.\left.\left.\left.\left.\left.+b_{2}\right)+b_{3}\right)+b_{4}\right)+b_{5}\right)+b_{6}\right)+b_{w}\right)
\end{aligned}
$$

where:

$a_{w}-$ output value,

$S^{i} \quad$ - the number of neurons in the i-th layer,

$F^{i} \quad$ - the activation function in the i-th layer,

$I W$ - initial weights (represent the weights of the first layer neurons, where each weight is connected to the element of the input vector, as shown in Figure 3),

$L W$ - layer weights (combined with each of the elements of the previous layer's vector).

In the process of preparing the data teaching the artificial neural network, data from the current collector measuring cards were used. In order to accurately map the wear processes, we can treat contact strip consumption as a function dependent on various parameters. Table 1 presents such features, which were considered to be one measurement. This measurement was made on a monthly basis and, in addition to the operational data, included information about the potential replacement of the contact strip and the pantograph.

Each training case used to train the ANN consisted of five such measurements as input data, while measurements from the sixth month were the output values (Fig. 4).

On the basis of data from pantograph measuring cards (operational data) and information about replacement of contact strip and the pantograph, a total of 919 training cases were prepared. 733 of these training cases were used in the learning (training) phase of the artificial neural network. The size of the input training matrix was therefore $40 \times 733$, while the output 
matrix was $8 \times 733$. For simulation, however, the remaining 186 training cases were used, containing only the input data from the next five months (matrix size $40 \times 186$ ), and the result of the simulation were target values has matrix size $8 \times 186$.

Table 1. The features for the ANN structure used in one measurement

\begin{tabular}{|l|c|}
\hline \multicolumn{1}{|c|}{ FEATURE } & SYMBOL \\
\hline \multicolumn{1}{|c|}{ MEASUREMNT } \\
\hline Current collector type & (Tp) \\
\hline Thickness of the first carbon contact strip & (THcs1) \\
\hline Thickness of the second carbon contact strip & (THcs2) \\
\hline Replacement of the entire collector & (Rcs) \\
\hline $\begin{array}{l}\text { Replacement of the current collector contact strip } \\
\text { Replacement of the cover due to wear } \\
\text { (abrasive wear, erosion wear) }\end{array}$ & (R1) \\
\hline $\begin{array}{l}\text { Replacement of the overlay caused by damage (detachment of } \\
\text { a piece of carbon strip, peeling off the top layer of a carbon strip, } \\
\text { overburning of the strip) }\end{array}$ & $\begin{array}{l}\text { (R2) } \\
\text { Replacement of the cover due to changes in regulation } \\
\text { (uneven wear of the sliders) }\end{array}$ \\
\hline
\end{tabular}

\begin{tabular}{|c|c|c|c|c|c|}
\hline \multicolumn{5}{|c|}{$\begin{array}{l}\text { INPUT } \\
(40 \times 1)\end{array}$} & $\begin{array}{l}\text { OUTPUT } \\
(8 \times 1)\end{array}$ \\
\hline $\begin{array}{c}\text { Measurement } 1 \\
(8 \times 1)\end{array}$ & $\begin{array}{c}\text { Measurement } 2 \\
(8 \times 1)\end{array}$ & $\begin{array}{c}\text { Measurement } 3 \\
(8 \times 1)\end{array}$ & $\begin{array}{c}\text { Measurement } 4 \\
(8 \times 1)\end{array}$ & $\begin{array}{c}\text { Measurement } 5 \\
(8 \times 1)\end{array}$ & $\begin{array}{l}\text { Measurement } 6 \\
(8 \times 1)\end{array}$ \\
\hline Tp (1) & $\mathrm{Tp}(2)$ & Tp (3) & Tp (4) & $\mathrm{Tp}(5)$ & $\operatorname{Tp}(6)$ \\
\hline THcs1 (1) & THcs1 (2) & THcs1 (3) & THcs1 (4) & THcs1 (5) & THcs1 (6) \\
\hline THcs2 (1) & THcs2 (2) & THcs2 (3) & THcs2 (4) & THcs2 (5) & THcs2 (6) \\
\hline $\mathrm{Rp}(1)$ & $\mathrm{Rp}(2)$ & $\operatorname{Rp}(3)$ & $\mathrm{Rp}(4)$ & $\mathrm{Rp}(5)$ & $\mathrm{Rp}(6)$ \\
\hline $\operatorname{Rcs}(1)$ & $\operatorname{Rcs}(2)$ & $\operatorname{Rcs}(3)$ & $\operatorname{Rcs}(4)$ & $\operatorname{Rcs}(5)$ & $\operatorname{Rcs}(6)$ \\
\hline R0 (1) & $\mathrm{RO}(2)$ & R0 (3) & R0 (4) & R0 (5) & R0 (6) \\
\hline R1 (1) & R1 (2) & R1 (3) & R1 (4) & R1 (5) & R1 (6) \\
\hline $\mathrm{R} 2$ (1) & $\mathrm{R} 2$ (2) & $\mathrm{R} 2$ (3) & R2 (4) & R2 (5) & R2 (6) \\
\hline
\end{tabular}

Fig. 4. Artificial Neural Network training case

\section{Results and conclusions}

The simulation results show that the output values largely correspond to the target values. The straight line coefficient for the training, validation and testing process was approximately 1 , and for training the value of shift factor $\beta$ was 0.012 , for validation $\beta=0.041$, while for testing $\beta=0.032$. This shows that the approximated function has been relatively well adjusted at this stage. 
Figure 5 shows the results of the simulation of the wear of carbon contact strips. As is clear from the histogram of the difference between simulation results and actual data (Figure 5a), there is an approximate number of underestimated (180) and overvalued (192) results of the simulation.

a)

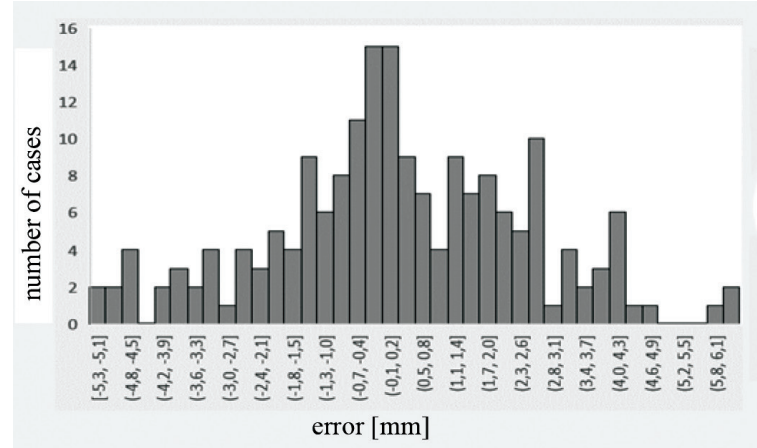

b)

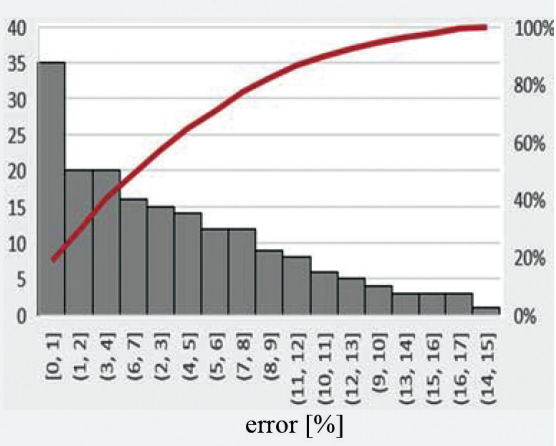

Fig. 5. a) Histogram of the difference in the thickness of the current collector sliding strip between the results of the simulation and the actual data; b) Pareto-Lorenz diagram of the percentage error in the thickness of the current collector sliding strip

The Pareto-Lorenz plot (Fig. $5 b$ ) shows that for $90 \%$ of the simulated cases, the difference between the actual value and the thickness value obtained during simulation does not exceed $12 \%$. A little below $20 \%$ of the results are within the error range of 0 to $1 \%$. Based on these results, it can be concluded that the created neuron network enables prediction of the consumption of the current collector carbon strip in a satisfactory manner.

The Feed-Forward Neural Network with backward propagation proposed in this paper allows the thickness of the pantograph sliding strip to be predicted only on the basis on data from the measurement notes. In summary, the work has shown that artificial neural networks are suitable for prediction of wear of sliding strips. In further work, it is planned to examine neural networks with different architectures and inputs in order to develop a system that supports the operational decision on replacing the sliding strips on the basis of predicted thickness value.

\section{References}

[1] EC Engeenering, Pantograf 160EC, http://www.ec-engineering.pl/produkcja/Zakład_ Produkcyjny-Kraków/Pantograf_kolejowy

[2] Abdullah M., Michitsuji Y., Nagai M., Integrated simulation between flexible body of catenary and active control pantograph for contact force variation control, Journal of Mechanical, 2010.

[3] Abdullah M., Michitsuji Y., Nagai M., Analysis of contact force variation between contact wire and pantograph based on multibody dynamics, Journal of Mechanical, 2010. 
[4] Aboshi M., Precise measurement and estimation method for overhead contact line unevenness, IEEJ Transactions on Industry Applications, 2004.

[5] Aboshi M., Manabe K., Analyses of contact force fluctuation between catenary and pantograph, Quarterly Report of RTRI, 2000.

[6] Allotta B., Pugi L., Bartolini F., An active suspension system for railway pantographs: the T2006 prototype, Engineers, Part F: Journal of Rail, 2009.

[7] Allotta B., Pugi L., Rindi A., Papi M., Innovative solutions for active railway pantograph, WIT Transactions, 2002.

[8] Chater E., Ghani D., Giri F., Haloua M., Outputfeedback control of pantograph-catenary system with adaptive estimation of catenary parameters, Journal of Modern Transportation, 2015.

[9] Gostling R.J., Hobbs A.E.W., The interaction of pantograph and overhead equipment: practical applications of a new theoretical method, Proceedings of the Institution of Mechanical Engineers, Part C: Journal of Mechanical Engineering Science, vol. 197, no. 1, 1983, 61-69.

[10] Judek S., Karwowski K., Mizan M., Diagnostyka i monitoring odbioru prąu z sieci trakcyjnej, Pojazdy Szynowe, 2011.

[11] Stichel S., Active Control of the Pantograph-Catenary Interaction in a Finite Element Model, 2013.

[12] Sitarz M.,Adamiec A., Mańka A., Uszkodzenia węglowych nakładekstykowych pantografów kolejowych stosowanych $w$ Polsce, TTS Technika Transportu Szynowego, 2016.

[13] Majewski W., Zastosowania nakładek weglowych w odbierakach prąu, Prezentacja Instytutu Kolejnictwa.

[14] Rusiecki A., Algorytmy uczenia sieci neuronowych odporne na blędy w danych, Wroclaw 2007.

[15] Hagan M.T., Menhaj M.B., Training feedforward networks with the Marquardt algorithm, IEEE transactions on Neural Networks, vol. 5, no. 6, 1994, 989-993.

[16] Marquardt D.W., An algorithm for least-squares estimation of nonlinear parameters, Journal of the society for Industrial and Applied Mathematics, vol. 11, no. 2, 1963, 431-441. 